\title{
REVIEW
}

\section{Injectable Coformulations in Diabetology}

Sanjay Kalra $\cdot$ Yashdeep Gupta

To view enhanced content go to www.diabetestherapy-open.com

Received: February 9, 2015 / Published online: March 24, 2015

(C) The Author(s) 2015. This article is published with open access at Springerlink.com

\begin{abstract}
Coformulations are a novel pharmaceutical development in diabetology. They are composed of two medicinal products, both of which maintain their distinct pharmacokinetic and pharmacodynamic properties. Currently available coformulations include combinations of basal and rapid-acting insulin, and basal and glucagon-like peptide 1 receptor agonists (GLP1RA). This review describes three coformulations which are in advanced stages of development, or are approved in certain markets. We discuss the basic and clinical pharmacology of these drugs, while describing clinical usage of the commercially available insulin degludec aspart (IDegAsp).
\end{abstract}

Electronic supplementary material The online version of this article (doi:10.1007/s13300-015-0106-2) contains supplementary material, which is available to authorized users.

S. Kalra $(\bowtie)$

Bharti Hospital and B.R.I.D.E, Karnal, Haryana

132001, India

e-mail: brideknl@gmail.com

Y. Gupta

Government Medical College and Hospital, Chandigarh, India
Keywords: BEGIN; BOOST; DUAL; GetGoal; Insulin degludec aspart; Insulin degludec liraglutide; Insulin glargine lixisenatide

\section{COFORMULATIONS IN DIABETOLOGY}

Fixed dose combination (FDCs) and fixed ratio combinations (FRCs) or fixed proportion combination (FPCs) are an integral and wellaccepted part of diabetes care. Oral FDCs are convenient to use and well tolerated in patients, and their efficacy has been well demonstrated [1]. Injectable FRCs or FPCs, such as pre-mixed insulin, are also widely used in diabetes management [1]. These FRCs provide convenient, effective and safe glycemic control. However, the traditionally available FRCs are mixtures of two components which merge with each other in the solution, and may lose their distinct pharmacokinetic and pharmacodynamic profiles [1]. This may lead to limitations in onset of peak or duration of action, and may result in suboptimal efficacy. Recently, injectable coformulations have been developed, which combine two distinct molecules in one formulation. These may be 
from the same therapeutic class (e.g., a rapid acting insulin combined with a basal insulin) or from different therapeutic classes (e.g., a basal insulin combined with a glucagon-like peptide 1 receptor agonist [GLP1RA]).

The dictionary defines "formulation" as "the act, process or result of formulating or reducing to a formula" or "a medicinal preparation", and defines coformulation as "the act of packaging more than one drug into one pill" [2]. It must be noted that no injectable coformulations have been described as such until now. The word "injection" when used in terms of drug dosage refers to solution, suspension and emulsion, including those produced from powders or concentrated solutions. Various oral coformulations such as multivitamins, vitamin B complex and certain antibiotics (e.g., co-amoxiclav) are available for intravenous use. Such pharmaceutical advances, however, have not been available in the anti-diabetic segment so far. This is because the challenges of producing and combining biologically engineered molecules, such as insulin and GLP1RA, are infinitely greater than those utilizing synthetic chemical compounds.

In this review, we define injectable pharmaceutical coformulations as preparations, and which also maintain their distinct pharmacological properties. These are distinct from the pre-mixed insulins that have been available over the last 50 years (Table 1 ).

\section{CLASSIFICATION}

In this review, we discuss the following coformulations, which are based on insulin as a common compound. These coformulations may or may not include a GLP1RA.

1. Ultra-long-acting insulin + rapid-acting insulin:

(a) Insulin degludec aspart (IDegAsp)

2. Insulin + GLP1RA:

Table 1 Coformulation versus pre-mixed preparation

\begin{tabular}{llc}
\hline Characteristic & Coformulation & Pre-mixed preparation \\
\hline Definition & $\begin{array}{l}\text { Formulation of two separate components, which maintain } \\
\text { distinct identity }\end{array}$ & $\begin{array}{c}\text { Mixture of two components, which } \\
\text { are unable to maintain distinct } \\
\text { identity }\end{array}$ \\
$\begin{array}{l}\text { Appearance } \\
\text { Proportion }\end{array}$ & Clear & Cloudy \\
$\begin{array}{l}\text { Pharmacokinetics/ } \\
\text { pharmacodynamics }\end{array}$ & Both components maintain distinct PK/PD profiles & Pre-determined \\
Efficacy & Both components achieve efficacy at targeted endpoint & Both components often achieve \\
& & targeted end points \\
Scope & Allows coformulation of separate classes of drugs & Does not allow mixing of different \\
& & classes of drugs
\end{tabular}

$P D$ pharmacodynamics, $P K$ pharmacokinetics 
(a) Insulin degludec liraglutide (IDegLira)

(b) Insulin glargine lixisenatide (IGlarLixi)

\section{INSULIN DEGLUDEC AND INSULIN ASPART}

Insulin degludec and insulin aspart (IDegAsp) is a novel, soluble coformulation comprising insulin degludec, an ultra-long-acting basal insulin analog, and insulin aspart, a rapidacting insulin analog. This coformulation is made up of $70 \%$ insulin degludec and 30\% insulin aspart.

Insulin degludec forms a soluble and stable dihexamer, using phenol and zinc. While zinc is responsible for the formation of hexamers, phenol maintains the molecule in a dihexameric form so that the multihexamers are not formed in the solution. Following injection into the subcutaneous tissue, phenol diffuses away from the formulation leading to the formation of multihexamer chains, which act by causing a slow, continuous and extended release of monomers from the injection site [3]. Insulin degludec has a very long duration of action $(>42 \mathrm{~h})$ with four times lower glycemic variability than insulin glargine at steady-state concentration [3]; this translates into a much lower risk of hypoglycemia, especially nocturnal hypoglycemia, as seen in various clinical trials [4].

\section{Pharmacokinetics and Pharmacodynamics}

These two insulin analogs have been coformulated in such a manner that they neither interfere with the pharmacokinetics of each other nor cause any change in the mode of action of each other [5]. Receptor affinities of various newer insulins have always been a cause of concern, especially insulin-like growth factor 1 (IGF-1) receptor binding affinity, which could induce mitogenesis and carcinogenicity when at high levels. These properties of insulin degludec [6] and insulin aspart [7] were respectively investigated in vitro, as briefly mentioned in Table 2.

\section{Clinical Trial Program}

The efficacy and safety of IDegAsp has been studied in the phase 3 BOOST clinical trial program. These clinical studies were conducted in patients with both type 1 diabetes mellitus (T1DM) and type 2 diabetes mellitus (T2DM), both as once-daily (OD) and twice-daily (BID) dosing. The endpoints of this trial are summarized in Table 3.

\section{Regulatory Approval Status}

IDegAsp has recently received market approval in the European Union, Japan, Mexico, India and Bangladesh for the treatment of T1DM and T2DM.

\section{Posology}

As per the IDegAsp label, IDegAsp can be administered OD or BID with main meal(s). In

Table 2 Receptor binding and metabolic and mitogenic properties of insulin aspart and insulin degludec

\begin{tabular}{llll}
\hline & $\begin{array}{l}\text { Human } \\
\text { insulin }\end{array}$ & $\begin{array}{l}\text { Insulin } \\
\text { degludec }\end{array}$ & $\begin{array}{l}\text { Insulin } \\
\text { aspart }\end{array}$ \\
\hline $\begin{array}{l}\text { Insulin receptor } \\
\text { affinity }\end{array}$ & $100 \%$ & $13-15 \%$ & $92 \%$ \\
IGF receptor affinity & $100 \%$ & $2 \%$ & $81 \%$ \\
Metabolic potency & $100 \%$ & $8-20 \%$ & $101 \%$ \\
$\begin{array}{l}\text { Mitogenic potency } \\
\text { Mitogenic/metabolic }\end{array}$ & $100 \%$ & $4-14 \%$ & $58 \%$ \\
potency ratio & & $<1$ & $<1$ \\
\hline
\end{tabular}


Table 3 Phase 3 trial programs investigating IDegAsp in T1DM and T2DM

\begin{tabular}{|c|c|c|c|c|c|c|}
\hline Population $(n)$ & $\begin{array}{l}\text { IDegAsp } \\
\text { dosing } \\
\text { time }\end{array}$ & Weeks & $\begin{array}{l}\text { Non-inferior } \\
\text { HbA1C control }\end{array}$ & $\begin{array}{l}\text { ETD of } \\
\text { FPG } \\
(\mathbf{m m o l} / \mathrm{L})\end{array}$ & $\begin{array}{l}\text { Confirmed } \\
\text { hypoglycemia }\end{array}$ & $\begin{array}{l}\text { Nocturnal } \\
\text { hypoglycemia }\end{array}$ \\
\hline $\begin{array}{l}\text { T1DM: IDegAsp } \\
\text { OD + IAsp at remaining } \\
\text { meals versus IDet (OD/ } \\
\text { BD) + IAsp at time of } \\
\text { meals (548) [9] }\end{array}$ & $\begin{array}{l}\text { Any main } \\
\text { meal }\end{array}$ & 26 & $\begin{array}{l}\text { IDegAsp non- } \\
\text { inferior to } \\
\text { IDet + IAsp }\end{array}$ & 0.23 & $\begin{array}{l}9 \% \text { Lower } \\
\text { with } \\
\text { IDegAsp } \\
\text { (ns) }\end{array}$ & $\begin{array}{l}37 \% \text { Lower } \\
\text { with } \\
\text { IDegAsp } \\
(p<0.05)\end{array}$ \\
\hline $\begin{array}{l}\text { T2DM: IDegAsp OD with } \\
\text { major meal versus IGlar } \\
\text { OD (Japan) (296) [10] }\end{array}$ & $\begin{array}{l}\text { Any main } \\
\text { meal }\end{array}$ & 26 & $\begin{array}{l}\text { IDegAsp OD } \\
\text { decreased HbA1C } \\
\text { significantly more } \\
\text { than IGlar OD } \\
(p<0.001)\end{array}$ & 0.15 & $\begin{array}{l}\text { 27\% Lower } \\
\text { with } \\
\text { IDegAsp } \\
\text { (ns) }\end{array}$ & $\begin{array}{l}\text { 25\% Lower } \\
\text { with } \\
\text { IDegAsp } \\
\text { (ns) }\end{array}$ \\
\hline $\begin{array}{l}\text { T2DM: IDegAsp BID versus } \\
\text { BiAsp } 30 \text { BID (intensify } \\
\text { pre-mix 1) (446) [11] }\end{array}$ & $\begin{array}{l}\text { With two } \\
\text { major } \\
\text { meals }\end{array}$ & 26 & $\begin{array}{l}\text { IDegAsp non- } \\
\text { inferior to BiAsp } \\
30\end{array}$ & $\begin{array}{l}-1.14 \\
\quad(p<0.001)\end{array}$ & $\begin{array}{l}32 \% \text { Lower } \\
\text { with } \\
\text { IDegAsp } \\
(p=0.0049)\end{array}$ & $\begin{array}{l}73 \% \text { Lower } \\
\text { with } \\
\text { IDegAsp } \\
(p<0.0001)\end{array}$ \\
\hline $\begin{array}{l}\text { T2DM: IDegAsp BID versus } \\
\text { BiAsp } 30 \text { BID (intensify } \\
\text { pre-mix in all) (424) [12] }\end{array}$ & $\begin{array}{l}\text { With two } \\
\text { major } \\
\text { meals }\end{array}$ & 26 & $\begin{array}{l}\text { IDegAsp non- } \\
\text { inferior to BiAsp } \\
30\end{array}$ & $\begin{array}{l}-1.06 \\
(p<0.001)\end{array}$ & $\begin{array}{l}\text { No significant } \\
\text { difference }\end{array}$ & $\begin{array}{l}\text { 33\% Lower } \\
\text { with } \\
\text { IDegAsp } \\
\text { (ns) }\end{array}$ \\
\hline $\begin{array}{l}\text { T2DM: IDegAsp BID versus } \\
\text { BB regimen with OD IDeg } \\
\text { with IAsp 2-4 times a day } \\
\text { (274) }[13]\end{array}$ & $\begin{array}{l}\text { With two } \\
\text { major } \\
\text { meals }\end{array}$ & 26 & $\begin{array}{l}\text { IDegAsp did not } \\
\text { achieve non- } \\
\text { inferiority }\end{array}$ & -0.5 & $\begin{array}{l}\text { 19\% Lower } \\
\text { with } \\
\text { IDegAsp } \\
\text { BID (ns) }\end{array}$ & $\begin{array}{l}\text { 20\% Lower } \\
\text { with } \\
\text { IDegAsp } \\
\text { BID (ns) }\end{array}$ \\
\hline
\end{tabular}

$B B$ basal bolus, BiAsp biphasic insulin aspart 30/70, BID twice daily, ETD estimated treatment difference, FPG fasting plasma glucose, HbA1C glycated hemoglobin, IAsp insulin aspart, IDeg insulin degludec, IDegAsp insulin degludec aspart, ns not significant, IDet Insulin detemir, IGlar insulin glargine, $O D$ once daily, T1DM type 1 diabetes mellitus, T2DM type 2 diabetes mellitus

patients with T2DM, IDegAsp can be administered either alone or with oral antidiabetic medicinal products and in combination with bolus insulin. In patients with T1DM, IDegAsp is used in combination with short-/rapid-acting insulin with remaining meals. Dose adjustments are recommended to be primarily assessed based on fasting plasma glucose measurements. Flexibility in dosing time of IDegAsp allows for flexibility in the timing of insulin administration, as long as it is administered with main meal(s). If a dose of IDegAsp is missed, patients should not take an extra dose to make up for a missed dose, but can take the missed dose with the next main meal of that day and then resume the usual dosing schedule the following day.

The recommended total daily starting dose for patients with T2DM is 10 unit with the main meal(s), followed by individual dosage adjustments. The recommended starting dose of IDegAsp in patients with T1DM is $60-70 \%$ of 
the total daily insulin requirements with short-/ rapid-acting insulin at the remaining meals, followed by individual dosage adjustments.

Patients with T2DM switching from oncedaily basal or pre-mixed insulin therapy can be given unit-to-unit, once-daily IDegAsp at the same total insulin dose as the patient's previous total daily insulin dose. Patients switching from more than once-daily basal or pre-mixed insulin therapy can be converted to unit-to-unit, twicedaily IDegAsp at the same total insulin dose as the patient's previous total daily insulin dose. Patients switching from basal/bolus insulin therapy to IDegAsp will need to convert their dose based on individual needs. In general, patients are initiated on the same number of basal units.

\section{Special Populations}

IDegAsp can be used in elderly patients (aged $>65$ years) and in renal and hepatic impaired patients with intensified glucose monitoring [8]. The insulin dose should be adjusted on an individual basis. The safety and efficacy of IDegAsp in children and adolescents aged under 18 years have not been established, and so this coformulation is not currently approved for use in children.

\section{INSULIN DEGLUDEC AND LIRAGLUTIDE}

Insulin degludec and insulin liraglutide (IDegLira) is a fixed-dose, once-daily combination of ultra-long-acting insulin degludec and liraglutide, a GLP1RA. It has been developed for use in patients with T2DM and can be given in a single, daily subcutaneous injection. The use of insulin is often associated with hypoglycemia and weight gain, hence delaying the initiation and intensification of the insulin regimen [14]. When used alongside insulin, GLP1RAs can play an important complimentary role, as their use has been associated with a lower incidence of hypoglycemia and weight loss; this could be due to loss of appetite, as is often seen with the use of GLP1RA [14]. Therefore, when administered together, this combination can be very successful in the management of T2DM. The combined use of basal insulin and GLP1RA analogs has also been jointly recommended by the American Diabetes Association (ADA) and European Association for the Study of Diabetes (EASD) [14].

\section{Rationale}

Many studies combining basal insulin analogs with GLP1RA have shown synergistic beneficial effects of these therapies with better safety profiles.

In a 26-week randomized, open-label study of patients with poorly controlled T2DM, addition of liraglutide to metformin treatment followed by intensification with basal insulin (insulin detemir [IDet]) showed that $61 \%$ of participants completing the run-in achieved glycated hemoglobin (HbA1C) levels of $<7 \%$ (mean change -1.3\%) compared with liraglutide alone [15]. At 26 weeks, HbA1C further decreased by $0.5 \%$ with IDet versus a $0.02 \%$ increase without IDet (estimated treatment difference $-0.52 ; 95 \%$ confidence interval $[\mathrm{CI}]-0.68$ to $-0.36 ; p<0.0001)$. At week 26 , HbA1C levels of $<7 \%$ were achieved in $43 \%$ of patients taking IDet versus $17 \%$ patients not taking IDet. Sustained weight loss was observed during the study; however, there were higher rates of minor hypoglycemia in patients treated with IDet compared to without IDet (9.2 versus $1.3 \%, p=0.004$ ) [15]. 
The efficacy and safety of adding long-acting GLP1RA liraglutide OD versus adding shortacting insulin aspart (IAsp) OD to long-acting insulin degludec (IDeg) OD + metformin in subjects with T2DM was first investigated in the BEGIN: VICTOZA ADD-ON trial [16]. Eligible subjects completing 104 weeks of treatment with IDeg + metformin in preceding trials were randomized to intensify treatment by adding either liraglutide or IAsp OD, on top of IDeg + metformin if their HbA1C was $\geq 7 \%$ ( $\geq 53 \mathrm{mmol} / \mathrm{mol}$ ). After 104 weeks, a third arm was included to evaluate the durability of IDeg to maintain glycemic control over an additional 26 weeks comprising non-randomized subjects with $\mathrm{HbA} 1 \mathrm{C}$ of $<7.0 \%$. The results showed that IDegLira reduced HbA1C $(-0.74 \%$ points $)$ significantly more than IDegAsp $(-0.39 \%$ points; $p=0.0024) .49 .4 \%$ of subjects in the IDegLira arm and only $7.2 \%$ in the IDegAsp arm achieved $\mathrm{HbA} 1 \mathrm{C}$ of $<7 \%$ without confirmed hypoglycemia or severe hypoglycemia, and without weight gain $(p<0.0001)$. IDegLira subjects had significantly less confirmed and nocturnal confirmed hypoglycemia, and significantly greater weight loss $(-2.8 \mathrm{~kg})$ versus IDegAsp $(+0.9 \mathrm{~kg} ; p<0.0001)[16]$.

\section{Pharmacokinetics and Pharmacodynamics}

IDeg is a basal insulin with an ultra-long duration of action that forms soluble multihexamers at the injection site following subcutaneous administration and a half-life of $24 \mathrm{~h}$ [17]. Liraglutide is a human GLP1RA with 97\% homology. The peptide precursor of liraglutide is produced using recombinant DNA technology in yeast (Saccharomyces cerevisiae). In a dose escalation study in healthy subjects, five consecutive dose levels $(1.25, \quad 5.0, \quad 7.5, \quad 10.0$ and $12.5 \mu \mathrm{g} / \mathrm{kg})$ of liraglutide were given subcutaneously on day 1 and days 5 to 11 . A steady state was observed after three doses and the half-life was determined to be $12.6 \pm 1.1 \mathrm{~h}$ [18] .

\section{Phase 3 Clinical Trial Program}

The DUal Action of Liraglutide and Insulin Degludec in Type 2 Diabetes (DUAL) trial includes two phase 3a trials encompassing around 2000 people with T2DM. It was designed to study the efficacy and safety of combined use of insulin degludec and liraglutide. All treatments in both the trials were given subcutaneously and could be given at any time of day, provided the chosen time was used consistently every day.

The main features and the study results of both the DUAL programs (I and II) are shown in Table 4.

\section{Regulatory Approval Status}

IDegLira has been given market authorization by the European Medical Agency (EMA), which is valid throughout the $\mathrm{EU}$ [21].

\section{INSULIN GLARGINE AND LIXISENATIDE}

Lixisenatide is a new selective once-daily GLP1RA in development for the treatment of T2DM [22]. In a 13-week, phase II study, the optimal dose of lixisenatide was found to be $20 \mu \mathrm{g}$ OD. At this dose, significant improvements in HbA1C versus placebo were observed, with a good efficacy/tolerability ratio [22]. Lixisenatide has demonstrated dose-dependent improvements in post-meal glucose levels and suppression of postprandial glucagon secretion in patients with T2DM insufficiently controlled 
Table 4 DUAL I and DUAL II clinical trial program

\begin{tabular}{|c|c|c|c|}
\hline Population & $\begin{array}{l}\text { Number } \\
\text { of weeks }\end{array}$ & Non-inferior HbA1C & $\begin{array}{l}\text { Other important points regarding } \\
\text { confirmed hypoglycemia and } \\
\text { weight change }\end{array}$ \\
\hline $\begin{array}{l}\text { DUAL I: T2DM: IDegLira } \\
\text { OD versus insulin degludec } \\
\text { OD versus liraglutide OD } \\
(n=1663)[19]\end{array}$ & 26 & $\begin{array}{l}\text { Mean HbA1C decreased by } 1.9 \% \\
\text { with IDegLira, by } 1.4 \% \text { with insulin } \\
\text { degludec, and by } 1.3 \% \text { with } \\
\text { liraglutide. IDegLira was non- } \\
\text { inferior to insulin degludec } \\
(p<0.0001) \text { and superior to } \\
\text { liraglutide, }(p<0.0001)\end{array}$ & $\begin{array}{l}36 \% \text { Of patients on IDegLira, } 14 \% \text { of } \\
\text { patients on insulin degludec and } \\
52 \% \text { of patients on liraglutide } \\
\text { achieved HbA1C levels of }<7 \% \\
\text { without any weight gain and } \\
\text { hypoglycemia } \\
\text { Number of confirmed hypoglycemic } \\
\text { events per patient year was } 1.8 \text { for } \\
\text { IDegLira, } 2.6 \text { for insulin degludec } \\
\text { and } 0.2 \text { for liraglutide }\end{array}$ \\
\hline $\begin{array}{l}\text { DUAL II: T2DM: IDegLira } \\
\text { OD + metformin versus } \\
\text { IDeg OD + metformin } \\
(n=413)[20]\end{array}$ & 26 & $\begin{array}{l}\text { Superior HbA1C reduction with } \\
\text { IDegLira by } 1.9 \% \text { versus } 0.9 \% \text { by } \\
\text { insulin degludec }(p<0.0001)\end{array}$ & $\begin{array}{l}\text { Mean weight change of } 2.7 \mathrm{~kg} \text { with } \\
\text { IDegLira versus no weight change } \\
\text { with insulin degludec, }(p<0.0001) \\
\text { Comparable incidence of confirmed } \\
\text { hypoglycemia was seen in } 24 \% \text { of } \\
\text { patients on IDegLira versus } 25 \% \text { of } \\
\text { patients on insulin degludec }\end{array}$ \\
\hline
\end{tabular}

HbAIC glycated hemoglobin, IDegLira insulin degludec liraglutide, $O D$ once daily

with metformin, as well as pharmacodynamic effects consistent with a glucose-dependent effect on insulin secretion and suggested improvements in $\beta$-cell function [23].

\section{Clinical Trial Program}

A phase 3 clinical trial program named GetGoal, which included 10 clinical trials, has been carried out to establish the safety and efficacy of insulin glargine and lixisenatide combination for the management of patients of T2DM. Table 5 summaries a few important trials of GetGoal program.

\section{CONCLUSION}

IDegAsp is the first soluble coformulation with both the basal and bolus insulin components available with the pharmacokinetic profile well retained unlike the previously available biphasic insulin preparations. Also, no resuspension is required before using IDegAsp, unlike other biphasic insulin preparations. This coformulation has shown non-inferiority in HbA1C control in comparison to the currently available basal and pre-mixed insulins both as OD dosing and BID dosing with lower risk of hypoglycemia. It is anticipated to offer clinical advantage over currently available pre-mixed insulin suspensions.

GLP1RAs have been designed to restore and maintain incretin glucagon-like peptide 1 levels and attenuate postprandial plasma glucose excursions. Currently, four GLP1RAs are available for the treatment of T2DM: exenatide BID; a long-acting formulation, once weekly; liraglutide OD; and prandial lixisenatide OD. 
Table 5 GetGoal clinical trial program

\begin{tabular}{|c|c|c|c|}
\hline Study design $(n)$ & Weeks & Non-inferior HbA1C & $\begin{array}{l}\text { Other important points regarding } \\
\text { confirmed hypoglycemia and } \\
\text { weight change }\end{array}$ \\
\hline
\end{tabular}

\begin{tabular}{lc}
\hline $\begin{array}{l}\text { GetGoal Duo 1 [24]: double-blind, } 24 \\
\text { parallel group trial in which }\end{array}$ & $\begin{array}{c}\text { Adding lixisenatide to insulin } \\
\text { glargine further reduced HbA1C } \\
\text { patients not achieving target }\end{array}$ \\
by $0.71 \%$ versus $0.40 \%$ with \\
glargine were given lixisenatide or $<7 \%$ with insulin & placebo $(p<0.0001)$ \\
placebo as add on therapy (446) & More participants attained HbA1C \\
& $7 \%$ with lixisenatide (56\% versus \\
& $39 \% ; p<0.0001)$
\end{tabular}

$\begin{array}{ll}\begin{array}{l}\text { GetGoal-M [25]: double-blind } \\ \text { placebo-controlled study where the }\end{array} & \begin{array}{l}\text { From a baseline HbA1C of } 8.1 \%, \\ \text { administration of lixisenatide led }\end{array} \\ \text { patients were randomized to } & \text { to a decrease of }-0.9 \% \text { (morning } \\ \text { receive injections of lixisenatide in } & \text { injection) and }-0.8 \% \text { (evening } \\ \text { the morning, lixisenatide in the } & \text { injection) versus }-0.4 \% \text { with } \\ \text { evening, placebo in the morning, } & \text { placebo (primary end point) at } \\ \text { or placebo in the evening (680) } & 24 \text { weeks }\end{array}$

GetGoal-L [26]: efficacy and safety of lixisenatide as an add-on therapy to basal insulin was investigated in patients inadequately controlled on a combination of basal insulin \pm metformin (495)

Lixisenatide significantly reduced HbA $1 \mathrm{C}$ by $-0.7 \pm 0.1 \%$ versus $-0.4 \pm 0.1 \%$ with placebo at 24 weeks $(p=0.0002)$ and increased the proportion of patients achieving $\mathrm{HbA} 1 \mathrm{C}<7 \%$ (28.0\% versus $12.0 \%$ for placebo;
Lixisenatide reduced $2 \mathrm{~h}$ PPG more than placebo $(p<0.0001)$

Lixisenatide had a favorable effect on body weight $(-0.89 \mathrm{~kg}$ compared to placebo; $p=0.0012$ )

Nausea, vomiting, and symptomatic hypoglycemia $(3.3 \mathrm{mmol} / \mathrm{L})$ were more common with lixisenatide

Mild and transient nausea and vomiting were the most commonly reported and only notable treatment emergent adverse events

Hypoglycemia frequency was slightly higher in the lixisenatide groups versus placebo, but remained low with no cases of severe hypoglycemia $p<0.0001)$
Lixisenatide reduced body weight compared with placebo $(p<0.0001)$. A decrease in insulin dose at study end was seen with lixisenatide compared with placebo $(-5.6$ versus $-1.9 \mathrm{U} ; p=0.012)$

Incidence of symptomatic hypoglycemia was comparable (27.7\% for lixisenatide versus $21.6 \%$ for placebo), whereas four cases of severe hypoglycemia occurred in the lixisenatide group compared to none in the placebo group 
Table 5 continued

\begin{tabular}{|c|c|c|c|}
\hline Study design $(n)$ & Weeks & Non-inferior HbA1C & $\begin{array}{l}\text { Other important points regarding } \\
\text { confirmed hypoglycemia and } \\
\text { weight change }\end{array}$ \\
\hline $\begin{array}{l}\text { GetGoal-L-Asia [27]: adults } \\
\text { previously treated and } \\
\text { inadequately controlled with basal } \\
\text { insulin } \pm \text { sulfonylurea and were } \\
\text { randomized on lixisenatide or } \\
\text { placebo ( } 311)\end{array}$ & 24 & $\begin{array}{l}\text { Lixisenatide significantly improved } \\
\text { HbA1C by }-0.88 \% \text { compared to } \\
\text { placebo }(p<0.0001) \text { and more } \\
\text { patients treated with lixisenatide } \\
\text { achieved HbA1C of }<7 \% \\
\text { compared to placebo ( } 35.6 \% \text { versus } \\
5.2 \% ; p<0.0001)\end{array}$ & $\begin{array}{l}\text { There was a trend in weight } \\
\text { decreases in patients treated with } \\
\text { lixisenatide, with no statistically } \\
\text { significant differences between } \\
\text { lixisenatide and placebo } \\
\text { Symptomatic hypoglycemia was } \\
\text { similar in patients not receiving } \\
\text { sulfonylureas, but was more } \\
\text { frequent with lixisenatide versus } \\
\text { placebo ( } 32.6 \text { versus } 28.3 \% \text { ) }\end{array}$ \\
\hline
\end{tabular}

$P P G$ postprandial plasma glucose

Table 6 Comparison of IDegLira and IGlarLixi

\begin{tabular}{|c|c|c|}
\hline & IDegLira & IGlarLixi \\
\hline Components & $\begin{array}{l}\text { Combination of insulin degludec (basal insulin with } \\
\text { a half-life of } 25 \mathrm{~h} \text { and duration of action }>42 \mathrm{~h} \text { ), } \\
\text { and liraglutide (GLP1RA analog with half-life of } \\
13 \mathrm{~h} \text { and OD dosing) }\end{array}$ & $\begin{array}{l}\text { Combination of insulin glargine (basal insulin with a } \\
\text { half-life of } 12.5 \mathrm{~h} \text { and duration of action } 24 \mathrm{~h} \text { ), and } \\
\text { lixisenatide (a short acting GLP1RA analog with a } \\
\text { half-life of } 2.6 \mathrm{~h} \text { and OD dosing) }\end{array}$ \\
\hline $\begin{array}{l}\text { Phase } 3 \\
\text { program }\end{array}$ & Completed & Completed \\
\hline $\begin{array}{l}\text { Approval } \\
\text { status }\end{array}$ & $\begin{array}{l}\text { Approved by European Medical Agency for the } \\
\text { European Market }\end{array}$ & Not yet approved \\
\hline
\end{tabular}

GLPIRA glucagon-like peptide 1 receptor agonist, IDegLira insulin degludec and liraglutide, IGlarLixi insulin glargine and lixisenatide

Multiple studies are being conducted to establish the efficacy and safety of combining basal insulin to GLP1R agonists, and these combinations can provide additional glycemic control by reducing both fasting plasma glucose and, to a lesser extent, postprandial plasma glucose excursions, in addition to promoting weight loss and a low rate of hypoglycemia. Table 6 gives a summarized comparison of IDegLira and IGlarLixi.

\section{ACKNOWLEDGMENTS}

No funding or sponsorship was received for this study or publication of this article. All named authors meet the International Committee of Medical Journal Editors (ICMJE) criteria for authorship for this manuscript, take responsibility for the integrity of the work as a whole, and have given final approval for the version to be published. 
Conflict of interest. S. Kalra has been on speaker's bureau of Novo Nordisk A/S, Sanofi Aventis and Boerhinger Ingelheim. Y. Gupta declares no conflict of interest.

Compliance with ethics guidelines. This article is based on previously conducted studies and does not involve any new studies of human or animal subjects performed by any of the authors.

Open Access. This article is distributed under the terms of the Creative Commons Attribution Noncommercial License which permits any noncommercial use, distribution, and reproduction in any medium, provided the original author(s) and the source are credited.

\section{REFERENCES}

1. Kalra S. Aggressive treatment in newly diagnosed diabetes with fixed dose combinations. Med Updat. 2012;22:249-53.

2. WordSense.eu Dictionary. Formulation (English). http://www.wordsense.eu/formulation/. Accessed Mar 12, 2015.

3. Kalra S, Unnikrishnan AG, Baruah M, Kalra B. Degludec insulin: a novel basal insulin. Indian J Endocrinol Metab. 2011;15(Suppl 1):S12-6.

4. Garber AJ, King AB, Del Prato S, NN1250-3582 (BEGIN BB T2D) Trial Investigators, et al. Insulin degludec, an ultra-long acting basal insulin, versus insulin glargine in basal-bolus treatment with mealtime insulin aspart in type 2 diabetes (BEGIN Basal-Bolus Type 2): a phase 3, randomised, openlabel, treat-to-target non-inferiority trial. Lancet. 2012;379(9825):1498-507.

5. Jonassen I, Hoeg-Jensen T, Havelund S, Ribel U. Ultra-long acting insulin degludec can be combined with rapid-acting insulin aspart in a soluble coformulation. J Pept Sci. 2010;16(Suppl 1):32.

6. Nishimura E, Sørensen AR, Hansen BF, et al. Abstract 974. Insulin degludec: a new ultra-long, basal insulin designed to maintain full metabolic effect while minimizing mitogenic potential. Diabetologia. 2010;53(Suppl 1):S388-9.
7. Kurtzhals P, Schäffer L, Sørensen A, et al. Correlations of receptor binding and metabolic and mitogenic potencies of insulin analogs designed for clinical use. Diabetes. 2000;49(6):999-1005.

8. Kalra S. Insulin degludec aspart: the first coformulation of insulin analogues. Diabetes Ther. 2014;5(1):65-72.

9. Hirsch IB, Bode B, Courreges JP, et al. Insulin degludec/insulin aspart administered once daily at any meal, with insulin aspart at other meals versus a standard basal-bolus regimen in patients with type 1 diabetes: a 26-week, phase 3, randomized, open-label, treat-to-target trial. Diabetes Care. 2012;35(11):2174-81.

10. Onishi Y, Ono Y, Rabøl R, Endahl L, Nakamura S, et al. Superior glycaemic control with once-daily insulin degludec/insulin aspart versus insulin glargine in Japanese adults with type 2 diabetes inadequately controlled with oral drugs: a randomized, controlled phase 3 trial. Diabetes Obes Metab. 2013;15(9):826-32.

11. Fulcher GR, Christiansen JS, Bantwal G, et al. Comparison of insulin degludec/insulin aspart and biphasic insulin aspart 30 in uncontrolled, insulin-treated type 2 diabetes: a phase $3 a$, randomized, treat-to-target trial. Diabetes Care. 2014;37(8):2084-90.

12. Kaneko S, Chow F, Choi DS, et al. Insulin degludec/ insulin aspart versus biphasic insulin aspart 30 in Asian patients with type 2 diabetes inadequately controlled on basal or pre-/self-mixed insulin: a 26-week, randomised, treat-to-target trial. Diabetes Res Clin Pract. 2015;107(1):139-47.

13. Cooper JG, Pieber TR, Cariou B, Endahl L, Zacho J, Rodbard HW. Treatment intensification with IDegAsp BID vs IDeg OD plus IAsp in insulintreated patients with type 2 diabetes: a randomised, controlled phase 3 trial. EASD 2014; Abstract 147. http://www.easdvirtualmeeting.org/resources/16863. Accessed Mar 9, 2015.

14. Inzucchi SE, Bergenstal RM, Buse JB, American Diabetes Association (ADA); European Association for the Study of Diabetes (EASD), et al. Management of hyperglycemia in type 2 diabetes: a patientcentered approach: position statement of the American Diabetes Association (ADA) and the European Association for the Study of Diabetes (EASD). Diabetes Care. 2012;35(6):1364-79.

15. DeVries JH, Bain SC, Rodbard HW, LiraglutideDetemir Study Group, et al. Sequential intensification of metformin treatment in type 2 diabetes with liraglutide followed by randomized addition of basal insulin prompted by A1C targets. Diabetes Care. 2012;35(7):1446-54. 
16. Mathieu C, Rodbard HW, Cariou B, et al. A comparison of adding liraglutide versus a single daily dose of insulin aspart to insulin degludec in subjects with type 2 diabetes (BEGIN: VICTOZA ADD-ON). Diabetes Obes Metab. 2014;16(7):636-44.

17. Heise T, Hovelmann U, Nosek L, et al. Abstract 1046. Insulin degludec: two-fold longer half-life and a more consistent pharmacokinetic profile than insulin glargine. Diabetologia. 2011;54(Suppl 1):S425.

18. Agersø H, Jensen LB, Elbrønd B, Rolan P, Zdravkovic M. The pharmacokinetics, pharmacodynamics, safety and tolerability of NN2211, a new longacting GLP-1 derivative, in healthy men. Diabetologia. 2002;45(2):195-202.

19. Gough SCL, Bode B, Woo V, et al. Efficacy and safety of a fixed-ratio combination of insulin degludec and liraglutide (IDegLira) compared with its components given alone: results of a phase 3, open-label, randomised, 26-week, treat-to-target trial in insulin-naïve patients with type 2 diabetes. Lancet Diabetes Endocrinol. 2014;2(11):885-93.

20. Buse JB, Vilsbøll T, Thurman J, NN9068-3912 (DUAL-II) Trial Investigators, et al. Contribution of liraglutide in the fixed-ratio combination of insulin degludec and liraglutide (IDegLira). Diabetes Care. 2014;37(11):2926-33.

21. European Medicines Agency. EMA/462053/2014; EMEA/H/C/002647EPAR summary for the public. London: EMA, 2014. http://www.ema.europa.eu/ docs/en_GB/document_library/Summary_of_opinio n_-_Initial_authorisation/human/002647/WC50017 0171.pdf. Accessed Mar 9, 2015.

22. Ratner RE, Rosenstock J, Boka G, DRI6012 Study Investigators. Dose dependent effects of the once- daily GLP-1 receptor agonist lixisenatide in patients with Type 2 diabetes inadequately controlled with metformin: a randomized, double-blind, placebo controlled trial. Diabet Med. 2010;27(9):1024-32.

23. Ratner RE, Rosenstock J, Boka G, Silvestre L. Abstract 131. Post-meal pharmacodynamic profile of AVE0010, a once-daily GLP-1 receptor agonist, in patients with type 2 diabetes inadequately controlled on metformin. Diabetologia. 2009;52 (Suppl 1):S60.

24. Riddle CM, Forst T, Aronson R, et al. Adding oncedaily lixisenatide for type 2 diabetes inadequately controlled with newly initiated and continuously titrated basal insulin glargine: a 24-week, randomized, placebo-controlled study (GetGoalDuo 1). Diabetes Care. 2013;36(9):2497-503.

25. Ahrén B, Leguizamo Dimas A, Miossec P, Saubadu S, Aronson R. Efficacy and safety of lixisenatide oncedaily morning or evening injections in type 2 diabetes inadequately controlled on metformin (GetGoal-M). Diabetes Care. 2013;36(9):2543-50.

26. Riddle $\mathrm{M}$, Aronson $\mathrm{R}$, Home $\mathrm{P}$, et al. Adding oncedaily lixisenatide for type 2 diabetes inadequately controlled by established basal inulin: a 24-week, randomized, placebo-controlled comparison (GetGoal-L). Diabetes Care. 2013;36(9):2489-96.

27. Seino Y, Min KW, Niemoeller E, Takami A, EFC10887 GETGOAL-L Asia Study Investigators. Randomized, double-blind, placebo-controlled trial of the once-daily GLP-1 receptor agonist lixisenatide in Asian patients with type 2 diabetes insufficiently controlled on basal insulin with or without a sulfonylurea (GetGoal L-Asia). Diabetes Obes Metab. 2012;14(10):910-7. 